\title{
Strategies of Development of Marine Ecotourism in Pagarjaya Village - District of Pesawaran - Lampung - Indonesia
}

\author{
Supra Jaya Perdana ${ }^{1}$, Abdullah Aman Damai ${ }^{1}$, Endang Linirin Widiastuti ${ }^{1, *}$ \\ ${ }^{1}$ Graduate School of Coastal and Marine Management, Universitas Lampung, Jl. S. Brodjonegoro No. 1, Bandar \\ Lampung, Indonesia \\ *Corresponding author. Email: elwidi@yahoo.com
}

\begin{abstract}
This study aims to determine the perceptions of visitors and the village community of Pagarjaya towards its marine ecotourism and to find out the suitable strategy for the sustainable management of marine ecotourism. The research was conducted in the village of Pagarjaya, Punduh Pedada, Pesawaran District, Lampung Province of Indonesia. The data used in this study were obtained through data collection techniques by means of interviews then the data were processed using the Likert scale method and SWOT analysis was performed. The Likert scale was used to explain the perceptions of tourists and coastal communities towards marine ecotourism in the village of Pagarjaya by determining a score for each question. Meanwhile, SWOT analysis was used to identify strengths, weaknesses, opportunities, and threats which can be used to elaborate the potential for marine ecotourism in the village of Pagarjaya. Interviews were conducted with the village community of Pagarjaya, tourists, civil servants of Tourism Office of the Pesawaran District and the head village of Pagarjaya. The results showed that instead of its high potential of marine ecosystem, the development of marine ecotourism in the village of Pagarjaya was still not optimal. Facilities, infrastructure, promotions, road access to marine ecotourism in the village of Pagarjaya were needed, while the right strategy for the development of marine ecotourism in the village of Pagarjaya was to elaborate more in Wayang islands and Teluk Hantu as the main destination of marine ecotourism. In addition to it, promotion or marketing, increasing cooperation with the government, and increasing the empowerment of the village community of Pagarjaya were the most crucial to be done.
\end{abstract}

Keywords: Ecotourism, Pagarjaya, Pesawaran

\section{INTRODUCTION}

Indonesia is well known to be one of archipelago country with 16,056 verified islands and with $81,000 \mathrm{~km}$ of coastline [1]. The nature potential of the Indonesian small islands was mostly fishery as well as mariculture and ecotourism [2].

Lampung Province is one of the Indonesian provinces with many potential marine ecotourism destinations. This province covers $35,367.5 \mathrm{~km}^{2}$ of land area with coastline of $1,105 \mathrm{~km}$ and total water area is $51,991 \mathrm{~km}^{2}$ contributed to 71 small islands [3]. Its districts with the highest number of small island is Pesawaran District. Under regional regulation of Pesawaran District Number 4/2012 about Areal Planning Management of Pesawaran District year 2011 - 2031, it listed that 37 small islands are under governed by Pesawaran District. Many of its coastal line as well as small island potential of marine ecotourism are not well explored, one of which is coastal village of Pagarjaya. Many coastal line of Pagarjaya could be potential used for marine ecotourism, such as Cukuh
Gedang, Pantai Karang Menyingok, Batu Payung, Pantai Kucing Riang, Pantai Teluk Hantu, and Pulau Wayang, which 5 of them are coastal areas with white sandy and last one is consisted of three small islands. From these six location, two of them are well known for some adventurism/traveler, they are Pulau Wayang and Pantai Teluk Hantu. These two places are among other ecotourism destinations in Lampung Province, especially in marine ecotourism area together with Puhawang island.

The most attractive of Pulau Wayang is these islands consisted of limestone islands with clear water and surrounding with coral reefs. The traveler called "small islands of Raja Empat of East Papupa Province" (see Figure 1). While the Pantai Hantu has white sandy beach with beautiful natural scenery (see Figure 1). Snorkling and diving are the most frequent activity in these two areas. Yet, all the infrastructure as well as all the equipment necessary for this activity are not available onsite of the area. 


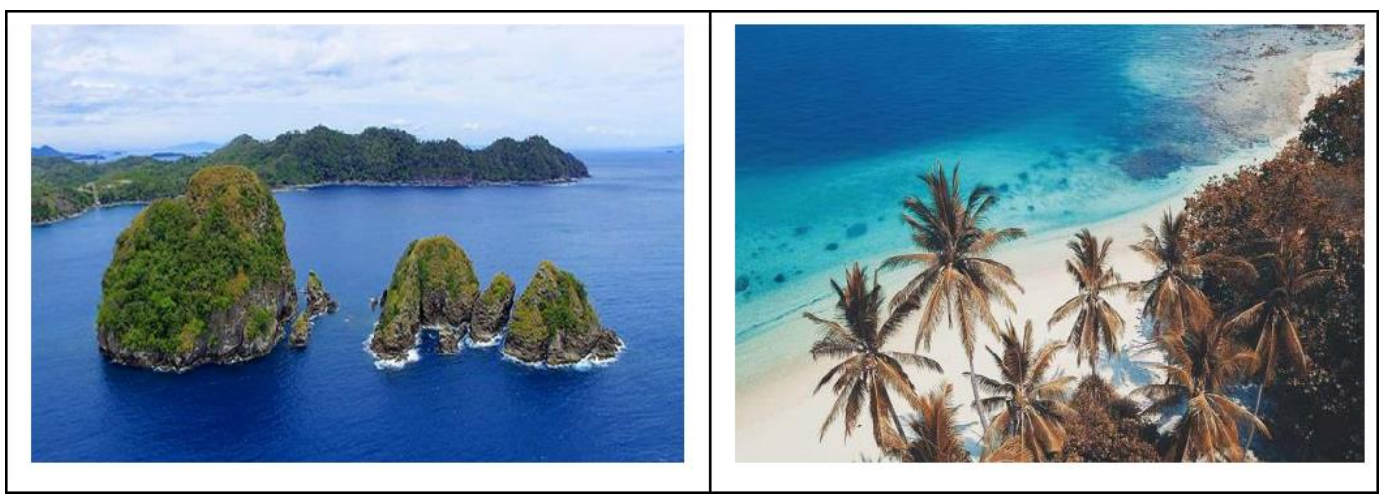

Figure 1. Pulau Wayang and Teluk Hantu - Pesawarn District of Lampung Province (source:kelilinglampung.net)

Therefore, this study was conducted to determine any suitable strategy for development of sustainable community based marine ecotourism.

\section{METHODS}

\subsection{Site Location and Time}

The study was conducted in Pagarjaya Village - Pesawaran District of Lampung Province (see Figure 2) on June - July 2020.

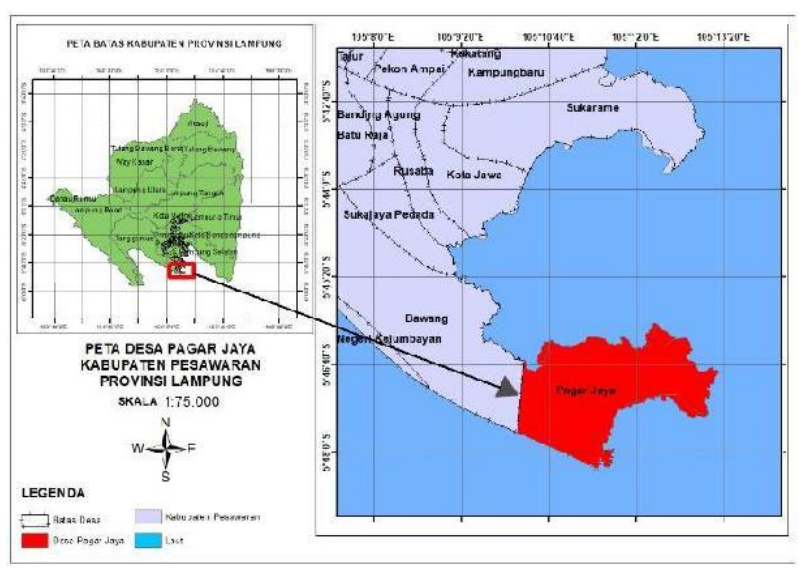

Figure 2. Pagarjaya Village of Pesawaran District Lampung Province

\subsection{Samples and Sample Size}

Samples used in this study consisted of local community of the Pagarjaya Village as well as the number of tourism in the last 5 years. Beside that the civil servant of Ecotourism Department of Pesawaran District and the head of the village. The size of samples then was calculated based on Slovin' formula as follow [4]:

$$
n=\frac{N}{1+N_{e}^{2}}
$$

In which:

$\mathrm{n} \quad=$ Number of sample

$\mathrm{N} \quad=$ The average tourism in the last 5 years

$\mathrm{e}=$ error rate of $10 \%$ and $90 \%$ confidence

$1=$ constant number

All data used in this study were collected from questioners to all respondent samples. All data then were calculated by using Likert Scale (Table 1). This analysis then used to explore the tourism and local community perceptions on the marine ecotourism of Pagarjaya Village. Likert scale was used to determine attitude, comment and perception of someone in term of social phenomena [5].

Table 1. Likert Scale and Scoring used in the study

\begin{tabular}{|l|c|}
\hline \multicolumn{1}{|c|}{ Statement } & Score \\
\hline Strongly Agree (SA) & 5 \\
Agree (A) & 4 \\
Doubt/Average (DA) & 3 \\
Disagree (D) & 2 \\
Strongly Disagree (SD) & 1 \\
\hline
\end{tabular}

All collected data from respondent then was tabulated and the percentage was calculated based on the Obtaining Level of Respondent (OLR) followed by descriptively analysis. [4]:

Calculation of OLR was based on formula as follow

\section{x $100 \%$}

The Obtaining Level of Respondent then was classified as follow (Table 2). 
Table 2. Percentage of OLR

\begin{tabular}{|l|l|}
\hline Percentage & Classification \\
\hline $90 \%-100 \%$ & Very Good \\
$80 \%-<90 \%$ & Good \\
$65 \%-<80 \%$ & Average \\
$55 \%-<65 \%$ & Not Good \\
$0 \%-<55 \%$ & Bad \\
\hline
\end{tabular}

\subsection{Strategic Analysis of Ecotourism Development of Pagarjaya Village}

The analysis strategy for Ecotourism Development of Pagarjaya Village was conducted by using SWOT (strength, weakness, opportunities and threats). SWOT analysis was performed to identify all factors in systematically ways [7], therefore the planning and strategy could be obtained for sustainable development of marine ecotourism in Pagarjaya Village.

\section{RESULTS AND DISCUSSION}

The SWOT analysis could be seen in tables as follows.

Table 3. Internal Factors on Marine Ecotourism Strategy Development of Pagarjaya Village

\begin{tabular}{|c|c|c|}
\hline Strength & & Weakness \\
\hline $\begin{array}{l}\text { 1. Natural resources } \\
\text { of Pulau Wayang } \\
\text { and Teluk Hantu }\end{array}$ & 1 & $\begin{array}{l}\text { Quality for access to the } \\
\text { destination is still under } \\
\text { proper }\end{array}$ \\
\hline $\begin{array}{l}\text { 2. Underwater } \\
\text { Biodiversity of } \\
\text { Pagarjaya } \\
\text { Village }\end{array}$ & 2 & No or lack promotion \\
\hline $\begin{array}{l}\text { 3. Hospitality of } \\
\text { local community } \\
\text { of Pagarjaya }\end{array}$ & 3 & $\begin{array}{l}\text { Weak creativity of the } \\
\text { local community to } \\
\text { support ecotourism } \\
\text { activity }\end{array}$ \\
\hline \multirow{2}{*}{$\begin{array}{l}\text { 4. Entry fee/ticket is } \\
\text { considered very } \\
\text { cheap }\end{array}$} & 4 & $\begin{array}{l}\text { Minimum quality of } \\
\text { local community }\end{array}$ \\
\hline & 5 & $\begin{array}{l}\text { Minimum facilities to } \\
\text { support ecotourism in } \\
\text { Pagarjaya village }\end{array}$ \\
\hline
\end{tabular}

Meanwhile, the external factor for development strategy for ecotourism in Pagarjaya Village could be seen in Table 4.
Table 4. External Factors on Marine Ecotourism Strategy Development of Pagarjaya Village

\begin{tabular}{|c|c|}
\hline Opportunities & Threat \\
\hline $\begin{array}{l}\text { 1. Improvement on } \\
\text { local incomes }\end{array}$ & $\begin{array}{l}1 \text { Degradation of } \\
\text { the marine and } \\
\text { coastal } \\
\text { ecosystem }\end{array}$ \\
\hline $\begin{array}{l}\text { 2. Increase in the } \\
\text { number of tourism }\end{array}$ & \\
\hline $\begin{array}{l}\text { 3. Increase in job } \\
\text { oppotunities }\end{array}$ & \\
\hline $\begin{array}{l}\text { 4. Local government } \\
\text { supports }\end{array}$ & \\
\hline $\begin{array}{l}\text { 5. Coral Reefs } \\
\text { conservation area of } \\
\text { Pagarjaya Village }\end{array}$ & \\
\hline
\end{tabular}

The Internal Factor Analysis Strategy (IFAS) and External Factor Analysis Strategy (EFAS) could be seen in Table 5 and 6 .

Table 5. IFAS for Ecotourism Development in Pagarjaya Village

\begin{tabular}{lccc}
\hline \multicolumn{1}{c}{ Internal Factor } & Rating & Value & Score \\
\hline $\begin{array}{l}\text { Strenght } \\
\text { Natural resources of } \\
\text { Pulau Wayang \& Teluk } \\
\text { Hantu }\end{array}$ & 4 & 0.18 & 0.72 \\
$\begin{array}{l}\text { Underwater biodiversity } \\
\text { of Pagarjaya }\end{array}$ & 3 & 0.17 & 0.51 \\
$\begin{array}{l}\text { Hospitality of local } \\
\text { community } \\
\text { Entry fee/tickets }\end{array}$ & 4 & 0.13 & 0.51 \\
\hline Sub total & 4 & 0.14 & 0.56 \\
\hline $\begin{array}{l}\text { Weakness } \\
\text { Quality of Destination }\end{array}$ & 2 & 0.10 & 0.19 \\
$\begin{array}{l}\text { Access } \\
\text { Promotion/Marketing }\end{array}$ & 2 & 0.12 & 0.24 \\
$\begin{array}{l}\text { Local creativity in } \\
\text { ecotourism business }\end{array}$ & 2 & 0.11 & 0.22 \\
$\begin{array}{l}\text { Local Community } \\
\text { Quality }\end{array}$ & 2 & 0.04 & 0.08 \\
$\begin{array}{l}\text { Facilities to support } \\
\text { marine ecotourism }\end{array}$ & 2 & 0.01 & 0.02 \\
\hline $\begin{array}{l}\text { Sub total } \\
\text { Total Value of IFE }\end{array}$ & & & 0.76 \\
\hline & & & 3.1 \\
\hline
\end{tabular}


Table 6. EFAS for Ecotourism Development in Pagarjaya Village

\begin{tabular}{|c|c|c|c|}
\hline External Factors & Rating & Value & Score \\
\hline \multicolumn{4}{|l|}{ Opportunities } \\
\hline $\begin{array}{l}\text { Improvement of local } \\
\text { income }\end{array}$ & 2 & 0.28 & 0.56 \\
\hline $\begin{array}{l}\text { Increase in number of } \\
\text { tourist }\end{array}$ & 2 & 0.19 & 0.39 \\
\hline $\begin{array}{l}\text { Development of hob } \\
\text { opportunity }\end{array}$ & 2 & 0.17 & 0.35 \\
\hline Local government supports & 3 & 0.15 & 0.44 \\
\hline $\begin{array}{l}\text { One of Coral conservation } \\
\text { area in Pesawaran District }\end{array}$ & 4 & 0.13 & 0.53 \\
\hline Sub total & & & 2.27 \\
\hline \multicolumn{4}{|l|}{ Threats } \\
\hline $\begin{array}{l}\text { Degradation of Coastal and } \\
\text { Marine ecosystem }\end{array}$ & 4 & 0.07 & 0.29 \\
\hline Sub total & & & 0.29 \\
\hline Total Value of EFE & & & 2.6 \\
\hline
\end{tabular}

SWOT analysis was used to identify the strength, weakness, opportunity and threat of development of potential marine ecotourism site of Pagarjaya village which also used for many different places [7][8][9]10]. Based on the analysis of the strength, weakness, opportunities and threat on the Pagarjaya village, not only for its natural resources but also local community as well as local government, the strategies that could be generated as follow:

1. Pulau Wayang (Wayang Islands) and Pantai Hantu were still in natural condition with their natural resources and they both could become a major tourism attraction for development of marine ecotourism in Pagarajaya village. The study indicated that mostly the tourisms came in the last 5 years were attracted to their natural beauty. They believed that this natural beauty was the major important to attract other tourism, therefore, they could increase in the number of visitors in Pagarjaya village.

2. Marketing or promotion should be generated by working together with tourism/travel agencies, especially those who run in marine ecotourism. Other possibility for promotion was to promote the tourism sites through social media or by international/national tourism festivals run by the district or provincial government. This marketing or promoting strategy aimed to increase the number of visitors/tourist and giving the opportunity to the visitors to gain all information in regard of marine ecotourism in Pagarjaya Village.

3. Increasing cooperation with the government to improve the quality of infrastructure, facilities and infrastructure to support marine ecotourism in the village of Pagarjaya. Improving the road mode, especially in the road mode in the village of Pagarjaya. Improving the road aims to facilitate the mobility of tourists who will visit.

4. Empowering the local community of Pagarjaya Village to support ecotourism. By community participatory involved of the local community may sustain the development of ecotourism [11]. Empowering could be generated by pushing and escorting them in actively providing home industry related to ecotourism, such as homemade culinary, souvenirs, since the nature resources provide for these both activities. Marine ecotourism activity, therefore, will improve household incomes in which could improve local welfares. Since many of ecotourism activity has a positive impact on economic conditions of local communities [12]. On the other hand, the marine ecosystems will be protected if they will be wellmanaged since many responsible visitors willing to pay for conservation of the ecosystem, such as those seen in Payar and Redang Islands in which already develop management policies that enhance ecotourism contribution to sustainable development and conservation in marine ecosystem [13].

\section{CONCLUSION}

In conclusion, the local community of Pagarjaya Village as well the tourist the existing marine ecotourism in Pagarjaya was still in minimum condition, therefore, it needs a lot of improvement not only in facilities but alos promotion and accessibility. Meanwhile, the strategies that are necessary to develop such as: (1). Strongly pursue that Pulau Wayang and Teluk Hantu are the major icon for marine ecotourism in Pagarjaya Village; (2). Promotion or marketing must be generated through tourism or travel agencies and other social media as well as tourism festivals internationally or nationally run by governments; (3). Working together or building up net working with the government to improve marine ecotourism facilities in Pagarjaya Village; (4). Community empowerment to support the marine ecotourism. 


\section{ACKNOWLEDGMENT}

Authors thanks to all people in Pagarjaya Village as well as the local government of Ecotourism Agency of Pesawaran District.

\section{REFERENCES}

[1] Dahuri R. 1993. Daya Dukung Lingkungan dan Pengembangan Pariwisata Bahari Berkelanjutan. Bogor : IPB.

[2] Dolman, A.J. 1990. The Potential Contribution of Marine Resources to Sustainable Development in Small-Island Developing Countries, in Beller, W.P. D'Ayala and P. Hein (Eds), Sustainable Development and Environmental Management of Small Island. Mand and the Biosphere Series, Volume 5. UNESCO, Paris and Parthenon Publishing Carnforth.

[3] BPS. 2016. Kabupaten Pesawaran dalam Angka. Badan Pusat Statistik Kabupaten Pesawaran, Lampung.

[4] Arikunto, S. 2006. Prosedur Penelitian Suatu Pendekatan Praktik. Jakarta: Rineka Cipta.

[5] Sugiyono. 2009. Metode Penelitian Kuantitatif Kualitatif, dan $R \&$ D. Bandung: Alfabeta.

[6] Rangkuti, F. 2006. Teknik Mengukur dan Strategi Meningkatkan Kepuasan Pelanggan. Jakarta: Penerbit PT Gramedia Pustaka Utama.

[7] Rahmat, M.A., S. Umar, Wardah, M. Nur. Sangadji. 2016. Potential and Strategy of Ecotourism Management in the Lore Lindu National Park (Case study in Sigi Regency, Central Sulawesi Province, Indonesia). Journal of Tourism, Hospitality and Sports. Vol. 22.
[8] Parmawati, R., H.W.P. Putra, A.S. Kurnianto. 2018. ECOTOURISM PLANNING ON THE RAPID-GROWING ECONOMIC AREA:A STUDY OF PACITAN, INDONESIA. ASEAN Journal on Hospitality and Tourism, Vol 16.2, pp. 54-70

[9] Arismiyanti, NK. 2020. DEVELOPMENT STRATEGY OF SUSTAINABLE MARINE ECOTOURISM IN INDONESIA. ASEAN Journal on Hospitality and Tourism, Vol. 15, pp. $118-138$.

[10] Fufurida, F., S. Oktavilla, SDW Prajanti, Y.A.Maretta. 2020. Sustainable Strategy: Karimunjawa National Park Marine Ecotourism, Jepara, Indonesia INTERNATIONAL JOURNAL OF SCIENTIFIC \& TECHNOLOGY RESEARCH VOLUME 9, ISSUE 03.

[11] Utami, P. R., and Mardiana, R. 2017. Hubungan Partisipasi Masyarakat Dengan Keberlanjutan Ekologi, Sosial-Budaya Dan Ekonomi Dalam Ekowisata Bahari. Jurnal Sains Komunikasi dan Pengembangan Masyarakat [JSKPM], 1(4), 509522.

[12] Zulpikar, F., L.A. Tambunan, S.R. Utami, W.E.Kiyat. 2018. Economic Valuation of Marine Tourism in Small Island Using Travel Cost Method (Case Study: Untung Jawa Island, Indonesia). Omni-Akuatika, 14 (1): 28-35.

[13] Yacob, M.R., A. Radam., A. Shuib. 2009. A Contingent Valuation Study of Marine Parks Ecotourism: The Case of Pulau Payar and Pulau Redang in Malaysia. Journal of Siustainable Development. Vol. 2 No.2.pp 95-105. 